\title{
Dispositions of Adults with Low Education Levels, and Who Haven't Returned to Formal Education, Towards Lifelong Learning
}

\author{
Vanessa Carvalho da Silva \\ PhD Student Sociology at ISCTE-IUL - Instituto Universitário de Lisboa (3rd year)
}

\begin{abstract}
This study aims to determine how adults with low education levels perceive lifelong education by analysing a set of interconnected and complementary aspects. The methodological strategy focussed on a qualitative analysis based on semi-directive interviews of a biographical nature. Identifying the reasons for the abandonment of initial (formal) education and obstacles faced by these adults over time revealed a myriad of factors justifying their disengagement from available education offers. To understand the amplitude of a phenomenon that links lifelong learning, knowledge, literacy and education level, in situations of a non-return to formal education, the study involved an in-depth analysis of the dispositions of persons who have "remained outside" of this relation with learning.
\end{abstract}

Keywords: Lifelong learning, knowledge society, adults with a low education level, dispositions.

\section{Introduction}

The centrality conferred on knowledge and information synchronically transformed schooling into an essential resource and indicator of inequality(educational). Converted into a leitmotiv of resource inequalities (Therborn, 2006), or category inequalities (Massey, 2007) - expressed in unequal distributions of educational resources, threatens the realization of an equal opportunity assumption.

The concept of a knowledge society (Drücker, 1969), in spite of the discussions that it provoked, has in its genesis the speed of social change (Jarvis, 2004: 15). Thus, in order to deal with these deeper and more systematic changes (idem), schooling has been understood as a vehicle for full integration of citizens in societies, protecting individuals from situations of precariousness and marginalization. Formal education thus becomes part of the relevant to the process of creating conditions for the realization of lifelong learning (LLL), considered a necessary strategy for adapting to a changing society, happens at an unprecedented speed ${ }^{1}$.

\section{Objectives}

The purpose of this exploratory study can be summed up in the need to outline the first lines for a deeper understanding of the relationship that low-educated adults have with education and lifelong learning. The questions that served as a guideline for this research were: to know the reasons why the active adult population (between the ages of 30 and 65) and low educated (covering levels of schooling between ISCED 1 and ISCED 2) did not attend adult education and training, or attended unsuccessfully; to explore their trajectories, exploring the different relationships that they establish through learning; understand what it means to live in society knowledge with low school qualifications; capture their perception about their non-participation in formal education / training modalities; understand if there are differences in the way of 'looking' at adult education and initial education, and identify them in the light of the interviewees' discourse.

Given what has been said, the analysis model presents as a central object the relationship of these adults with lifelong learning. Therefore, we sought to understand this relationship diachronically through their school trajectories, professional and training. The identification of its dispositions on education, adult education and training (AE) and Lifelong Learning (LLL) has been complemented by gathering information on its social origins and its proximity networks. Exploring the different views and expectations, held overreach one of its forms, it was tried to capture the experience of a distance with

${ }^{1}$ Educação e Transformação social (Enguita, 2007) 
the formal education and the constraints felt in the day to day of those who have low levels of schooling and moves in the designated society of the knowledge. In order to observe these obstacles, Jarvis typology was used (Jarvis, 1992: 245).

Given what has been said, the analysis model presents as a central object the relationship of these adults with lifelong learning. Therefore, we sought to understand this relationship diachronically through their school trajectories, professional and training. Identification of its provisions on education, adult education and training (AE) and Lifelong Learning (LLL) has been complemented by gathering information on its social origins and its proximity networks. Exploring the different views and expectations, held overreach one of its forms, it was tried to capture the experience of a distance with the formal education and the constraints felt in the day to day of those who have low levels of schooling and moves in the designated society of the knowledge. In order to observe these obstacles, Jarvis typology was used (Jarvis, 1992: 245). Aware that the analysis of this relationship with LLL should always be multidimensional, responding to the innumerable challenges that make up the daily life of adults in today's societies, we worked on the interconnection of all these dimensions, reserving the continuum that seems to exist between 'cause and effect'.

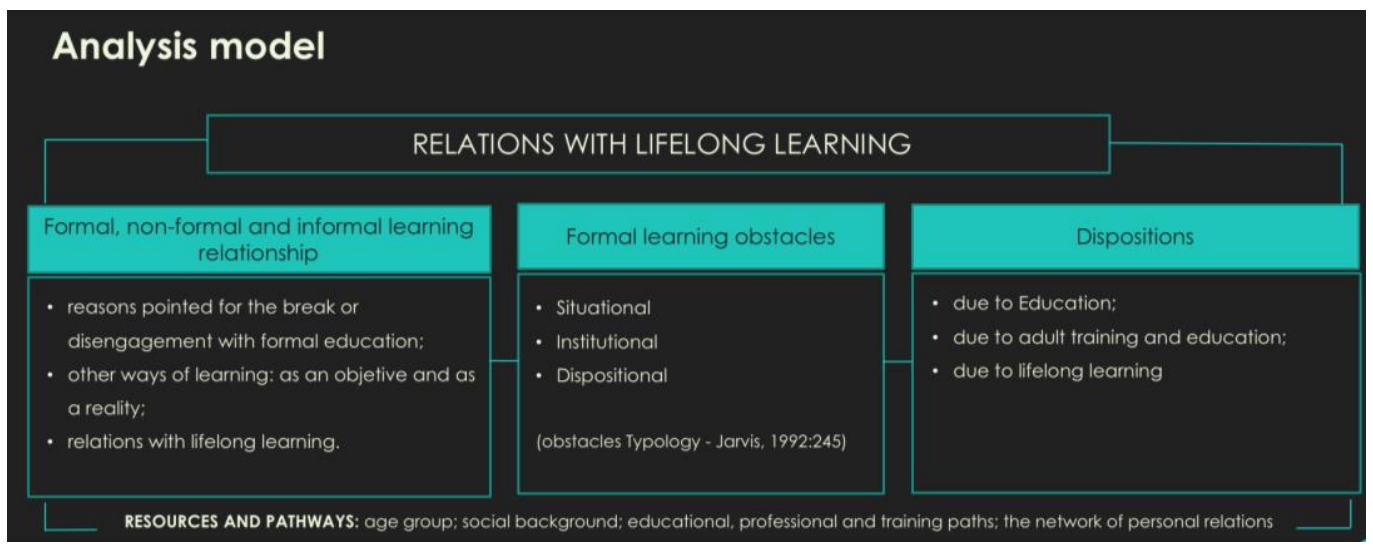

Figure 1 - analysis model (author)

Starting the research by the contextualization of the phenomenon in Portugal, through the results found in the second edition of the Adult Education Survey (AES) ${ }^{1}$, it was possible to verify that, despite the existence of a significant increase between 2007 and 2011, there were adults who persistently did not participate in any activity of formal, non-formal and informal education (2007: 30,9\%; 2011: 48,8\%).

The social weight of schooling and the fact that other forms of learning depend on it (informal and non-formal)2 ${ }^{2}$, making it an essential resource for $\mathrm{LLL}^{3}$, seems to contribute to the relevance of formal education. However, in Portugal, and despite the persistence of an adult population with low levels of schooling, of the $48,8 \%$ who participated in LLL activities, only $16.6 \%$ of the population was involved in formal education activities ( $6,5 \%$ did not have any level of education] (IEFA, 2011: 33-35).

Given their relevance, other research has sought to understand the relationship that low levels of schooling may have with other skills, such as literacy ${ }^{4}$. Previous studies have confirmed the existence of a relationship between levels of education and levels of literacy (Benavente, Rosa, Costa and Ávila, 1996; Ávila, 2008), confirming the existence of a "double" national handicap in the "race to knowledge". Literacy, multidimensional competence that has gained relevance in writing-dominated societies, translates into the ability to reflect/analyze reality critically, recognize emotions in a subjective sense, allowing

\footnotetext{
${ }^{1}$ Adult Education Survey (AES, 2011), Eurostat; In Portugal it is known as IEFA.

2 National Qualifications Catalog: the relationship between schooling and access to non-formal education offerings; the relationship between schooling and other forms of education/learning present in the two editions of IEFA (2007/2011); the relationship between literacy and schooling in Ávila 2008.

3 IEFA 2011, p. 34: '... participation in lifelong learning activities is strongly influenced by the level of education of the population'.

${ }_{4}^{4}$ Multidimensional concept (numeracy, digital/social skills, reading/writing skills, cognitive/affective, sociocultural/creative).
} 
self-recognition/self-efficacy, active citizenship, and an encounter with knowledge ${ }^{1}$. However, this knowledge, manipulated by individuals, forces them to decide, plan and reflect before making a decision, for which they only rely on their knowledge, and their ability to learn/adapt to a so-called learning society (Jarvis, 2004). Thus, literacy skills are now considered essential to find/maintain a job, to participate in the democratic system, to be an active consumer and to enjoy the benefits of digital/social/professional development.

Faced with this multidimensionality that reflects the relationship that individuals began to struggle with knowledge and education, some authors warned of the existence of individuals who have been marginalized (Field, 2006). Considering the limited availability of Adult Education and Training (EA) in the national education system, and the existence of a significant number of adults who have been 'on the sidelines', it is necessary to understand the place that this has occupied in the history of this system in Portugal ${ }^{2}$. Rodrigues et al. (2014) refer to it as a subsystem of a second chance education. Wrapped in advances and setbacks of 'transitional' policies and measures, in a country facing a deep-seated skill/education deficit of its population, the conclusions point to a system whose response has been limited.

In the assimilation of the relationship of these poorly educated adults, who did not return to formal education, through lifelong learning, the multidimensionality of LLL was incorporated. In this way, to understand it, responding to the challenges that imbue the daily life of adults in today's societies, in order to find the genesis of their dispositions due to LLL, their school, vocational/training, proximity networks, and social origins were considered in the analysis.

Faced with the school trajectories, there was a need to understand the process of withdrawal from formal learning, as well as the constraints experienced in the daily life of those who have moved in the knowledge society with low levels of schooling. Thus, in order to capture the separation process, identifying the main barriers, the Jarvis typology distinguishes them in three groups: situational, institutional and dispositional obstacles (Jarvis, 1992: 245). Knowing the obstacles, visions, and expectations around these types of learning, allowed to verify significant differences in the way these adults see the EA and the initial (formal) education.

\section{Brief methodological notes}

Inserted in a comprehensive perspective, the pertinence of a qualitative methodological approach was considered, materialized through the in-depth interview, based on a chronological background. With a strong descriptive and interpretative dimension, two systems of theoretical-analytical concepts were used as resources, one initial and the other, which was summoned throughout the analysis. We opted for the total transcription of the interviews, analyzing them thematically and problematically. The content analysis was based on the (re) reading of the interviews and on the grids, enriching each dimension through the appropriation of the meanings transmitted by each interviewee.

As an exploratory qualitative study, twelve adults, from Torres Vedras, whose social origin was predominantly rural, were interviewed. Selected by the snowball technique, subjects were between 30 and 64 years old and had an education level between an incomplete ISCED 1 ( $<4$ years) and ISCED 2. They were in different professional situations: unemployment/retirement, self-employed/employees and distributed in different activities: cleanings/agriculture, locksmithing/logistics, commerce, and industry.

Also considered to be relevant, as a complement to the analysis of the interviews, were the difficulties encountered in their implementation, namely situations of refusal. These situations occurred with less educated adults, in the approach/invitation to participate in the interview. Resistant to a possible evaluation, here interpreted as a defense strategy to deal with negative self-images, full of frailties and insecurities, the answer "I can't respond to nothing, I only have the 4th year (ISCED 1)! ", seems to converge with the warning about the" shame of those who do not know ", left by the EU High-Level Group of Experts on Literacy (2012).

Another aspect worthy of a reservation was the first interview, in which it was possible to verify that it had to be the more directive the lower the level of education of the interviewee, observing the need for an "external orientation" in the reflection on their trajectories. Therefore, the techniques were adjusted to the individuals, being reflected in a dynamic capable of enriching the analysis itself.

\footnotetext{
${ }^{1}$ EU High Level Group of Experts on Literacy (2012).

2 Read the work of Capucha (2013).
} 


\section{The relationship of under-educated adults to formal education}

\section{Leaving school: leaving or dropping out?}

In order to analyze the relationship with formal education, we tried to understand the reasons that were the origin of the rupture/withdrawal with the school.

The decision to leave school, despite having been lived differently in each one of the interviewees, was mostly associated with difficulties in learning, materialized in disapprovals and failures [negative evaluations] that discouraged them. This first conclusion, centered on the school trajectories of the adults, led the research to a more detailed understanding of the withdrawal, allowing to observe that, in all cases, it began long before it materialized.

Most school trajectories have revealed winding, negative and disapprovals paths [Seabra's school success measure unit, (2011: 82)], resulting in demotivation and lack of self-esteem. At the origin of the abandonment of formal education, these learning difficulties arose impregnated with self-responsibility in the face of failures, understood by these individuals as the result of their inability to learn:

Ana (64 years/ ISCED 1/cleanings): "[...] or the head did not ...I got it!"1;

Madalena (62 years/ISCED 1 incomplete/retired): "I do not know, it was stupid ... I did not learn enough!";

Mário (39 years old/incomplete ISCED 2/shopkeeper) "[...] was stupid [...] was to draw red, always";

This idea corroborated the existence of a meritocratic vision of education, deeply rooted in the premise that the future would depend on the merit of each one and that success/failure would result, first, from the merits of one's own student. In addition to failure (or its origin), negative experiences with the teacher and the school also determined the relationship with formal education:

Alfredo (41 years old / ISCED 1 / unemployed): "I did not like that ... it was a horrible environment [...] I was only there because I had to!";

Susana (54 years old/ISCED 2/Reformed): "[...] I never liked the school ... the school for me was a martyrdom!";

João (30 years old/ISCED 2/Storeman): "I did not like going to school at the time ... I remember well, the teacher was screaming a lot."

The warning about the multifactoriality of the reasons behind school drop-out is echoed in studies such as Benavente et al. (1994), Ferrão et al. (2000) cited in Ávila (2008). In Seabra (2010), one reads Bressoux to defend an analysis to the abandonment [rupture/withdrawa] able to privilege the combination of its multiple dimensions. From their contributions, the socio-economic conditions of families [educational resources, aspirations, projects against schooling] and the school experience were summoned in this analysis, which led to another essential point, the disadvantaged family contexts and the cost/benefit of the school against the call of the beginning of the professional life (idem).

At this point, we highlight the discussions of Bourdieu and Boudon on the mobilization of families in relation to the school (Seabra, 2010: 50). In an individualist/actionalist conception [concerning social inequalities] Boudon argued that the investment of families and students in schooling did not happen through internalization objective, but through the use of a rationality conditioned by its social position/class, based on a kind of cost/benefit type calculation (idem). This investment would, therefore, depend on its position and families and students would have a different estimate of costs/risks and benefits, determining their decisions about the school.

With a persistent problem of early school leaving, Portugal has been confronted cumulatively with challenges arising from the lag of the universalization of education and a labor market that is not very demanding in qualifications, attracting the young. Tânia Costa (2000) observed that dropout rates were more pronounced in rural areas, gaining expression in families with low levels of schooling, low incomes, and economic difficulties. In its origin, the author found on one side the role of a market that attracted young people and besieged them with the promise of financial autonomy, and on the other the presence of a school that has proved incapable of motivating them.

\footnotetext{
${ }^{1}$ The transcription of the interviewees' speeches respected the linguistic code of individuals.
} 
In the research that illustrates this article, the majority of respondents belonged to poorly schooled rural families whose professions ranged from agricultural wage earners to self-employed workers. The school coexisted with other activities that served as a financial complement to the family [work in the field, housework, sewing or collaboration in the activity of the parents], making it cost-effective for the school to lose relevance. For most of the families of the interviewees, the integration of children into working life was a fundamental resource in family subsistence:

Madalena (62 years/ISCED 1 incomplete/ex-administrative of her husband's company), born in a village on the west coast and left the school by will and decision of her mother, after some disapprovals. She used to work while she was at school, and when she left, she started to work at sewing: "We went to school and then when we left school ... the mother and father went to the farm and I had to put the food on the table [...] my mother took me when I was 12 years old [...] it was her who wanted me to learn to sew";

Luis (50 years/ISCED 1/former driver), born in a village in the center, left school at the age of thirteen by the will and decision of the parents to go to work in the field: "Parents also didn't allow it, they didn't have enough money ... it was "you already have a lot of work to do, you can't go to school, you have to go to work" [...] for the field, for the works [...] was to leave school and go to work soon.";

Pedro (62 years/ ISCED 1), left the school by parents' decision to help them financially, expressing the tension between their aspirations and the decision made: "I left school and I was very sorry for not studying at the time, not going to school, but since my parents had a lot of trouble, I felt obliged to help them ";

These testimonies expressed the presence of a conflict between the school [understood as a short-term project] and the work [guarantee and financial support of the family]. Considering it necessary to understand the relationship between these adults and the initial education, perceiving that it would translate into a withdrawal, the time of leaving the school, of each trajectory, was analyzed in light of the law that defined the level of compulsory schooling ${ }^{1}$. In this way, it was concluded that only a few individuals had left school fulfilling compulsory schooling. Consequently, in most cases, the prevalence of breakdown/dropout [pre-completion of compulsory schooling] among family tensions prevailed.

The oscillation and tension found between the will of the parents and the will in the decision to leave the school also allowed to verify that when the rupture happened by his own will, the failure and the negative relation with the school functioned as "triggers" opening up the attraction for the labor market and the desire to access consumer goods not supported by households.

Sérgio (34 years/locksmith/ISCED 2 incomplete), born in a village on the west coast near the city, left school, after some disapprovals voluntarily to go to work, continuing the work that already coexisted with the school (help the father in electricity): "I did the 9th grade, but I failed [...] did not want to repeat it ... my father is an electrician and he needed someone to help pull the wires ... that's where I started to enjoy working ... maybe 14/15 years old".

Mário (30 years/ISCED 2 incomplete/Storeman), decided to leave school, contradicting parents, after some disapprovals, unmotivated and disintegrated, "... I snorted once in the 8th and then went back to sinking in 9 ... I began to disperse because my colleagues were not the same, it was all younger people ... to start thinking about abandoning happened there. [...] who wanted to leave? I did! For my parents, it was the worst, but I would be upset too. "

Alfredo (41 years/ISCED 1/industrial worker), gave up the school by his will, after three disapprovals and not liking it, contrary to his mother's will: "I went to the preparatory cycle and I was there for 3 years because I didn't like it. My mother obliged me ... I didn't go to school, it was a terrible environment ... I hated being there!";

However, in both situations, and according to Boudon (idem) in the cost/benefit calculation, economic resources overcame, since the educational resources symbolized obstacles to the autonomy processes.

Bruno (41 years/ ISCED 2 incomplete/maintenance of swimming pools), left the school at his will to go to work: "I wanted to go to work, to have my things, my parents did not need help, but I saw my friends with motorbikes and such things, and I began to want. Then I said, "I'll work by day and study at night!" [...] I did it for a year, but it wasn't enough, because studying at night is difficult ... I was always going to the cafe".

\footnotetext{
1 See Decree Law no. 85/2009, of August 27.
} 
Within the singularities of the trajectories, there was a case where dropping out of school occurred as a consequence of the accumulation between school failure and a teenage pregnancy, indicating the need for an early transition into adult life. The case of Sónia (34 years/ISCED 1/unemployed> 12 months) can be summarized as follows: reproval-dating-withdrawalreturn-pregnancy-marriage-abandonment:

"I went back to the 1st year of ISCED 1, I stayed behind and then I failed in 4th grade ... I went from fourth to fifth year (ISCED 1), after the 5th year to the 6th, then I reproved again (ISCED 1) [...]l dropped out of school and started dating my son's father[...] I got to attend 7th year (ISCED 2), but then I didn't conclude it. So, that's how I ended up with only the 6th grade (ISCED 2) [...] Then, between the ages of 16 and 17, I got pregnant, and I got married at 18 [...] only after Diogo's birth I ended up for giving up the course".

Other cases similar to this can be read in the studies on young people and uncertain transitions, such as Guerreiro et al. (2004) and Alves et al. (2011).

Summarily, this study allowed us to verify that dropout occurred through different stresses: economic conditions, family, school, and society in general versus projects and expectations of these adults in relation to school/life. Capturing the internal dynamics of these tensions, it was observed that the cases of rupture by the will of the parents/family were accompanied by the disagreement of the individual, expressed through the recognition of the will to have remained in the school, since this would represent a vehicle for a better life. On the other hand, when the genesis of abandonment lay in the will of the individual, the tension resulted from the divergence of opinions about the school: oscillating between the perception of the family and society about a relationship between school progression and social mobility; and the representation of this same relationship as an obstacle to a faster process of autonomy for individuals.

\section{The relationship with other learning contexts: individual strategies?}

If in IEFA (2011) the operationalization of the LLL concept covered only formal and non-formal education, in its genesis ${ }^{1}$ we are referred to formal, non-formal and informal learning processes, which in itself calls for a multiplicity of forms and contexts to be taken into account in their analysis, breaking with less comprehensive visions that only privilege certified apprenticeships in specialized entities (Ávila, 2008: 306).

In the scope of this research, and in this dimension of analysis, the more comprehensive conception of the LLL was assumed, making it possible, after observing the reasons that led to abandonment/withdrawal from formal education, to identify other forms of learning in the life trajectories of these adults. From this analysis, we find what has been called the "individual strategy" and which represents a selection of the type of learning to be used throughout the different stages of trajectories, supported by a conscious need to mobilize resources.

Non-formal education ${ }^{2}$, commonly associated with the professional context, and informal learning ${ }^{3}$ integrated the trajectories of all the interviewees, although it was verified that the activities and resources used depended on the level of education and their situation at work. Regarding the relationship with informal learning and corroborating the results of the IEFA (2011) on participation in this type of activities ${ }^{4}$, the presence in the trajectories of all individuals was confirmed. For this group, the informal type of learning represented an accessible response to the needs imposed by the speed of social change, considered as an "atomic bomb of technologies and new things" (Susana/54 years/ISCED 2). However, in this relationship with learning the respondent valued individual characteristics as resources/tools for those who considered itself "learners": curiosity, self-learning, resourcefulness, and proactivity.

Alfredo (41 years/ISCED 1) made clear the presence of informal learning between "seeing-doing" and using his proximity networks (family/co-workers), or even self-learning, using manuals and of experience. Doesn't use the internet or computer, and with the mobile phone he has learned by trying and failing: "Once I found two birds that I didn't knew ... but then I spoke

\footnotetext{
${ }^{1}$ Memorandum for Lifelong Learning (2000).

2 Developed in the job or in the free time to improve knowledge or skills: courses, professional context, private lessons, and workshops or seminars; doesn't confer equivalence to any level of schooling.

3 Proximity networks/internet/reading manuals or magazines, other social activities that translate learning used/transferred to and between the different life dimensions of these individuals.

${ }^{4}$ It was attended by about two-thirds $(66.9 \%)$ of the Portuguese population, between 18 and 69 years.
} 
with a man who is a hunter and he said that they were the "dom fafe "... my uncle who was a fisherman taught me to tie fishhooks and that sort of thing ... had a very old manual";

Sérgio (34 years/ ISCED 2 incomplete), resistant to formal and non-formal education, based on the premise of 'needing work and not taking courses', has invariably turned to informal learning because, according to it, on his profession it was very important the experience and the ability to "unleash" itself. The Internet was the privileged resource for an autonomy process in their learning: "... No, what I learned, I learned alone! [...] you do not need a course [...] because you have developed skills over the years [...] when I have doubts [...] nobody knows them, I come to the internet and that's where I find the answer";

Madalena (62 years/ISCED 1 incomplete) presented an individual strategy based on continuous informal learning, driven by curiosity. His professional experience added to the characteristics which she considered to be the basis of her will to learn: "They taught me and I learned sewing [...] On the computer, my son has been helping me [...] I am learning more with a kid that I have ... I asked, because I knew how to read, I understood what I read ...I am one of those people who, when I don't know, I ask [...] I like to know, I like to be explained ... it is important to learn and every day you are learning a little bit of everything".

The relationship with non-formal education, mentioned by about half of the respondents, was inscribed in an obligatory relationship that did not always grant positive recognition. For the unemployed, it was imposed by the IEFP ${ }^{1}$, for the assets the imposition was of the company and few assumed it as part of its "individual strategy". In Portugal, participation in nonformal education activities covered $39.6 \%$ of the population between 25 and 64 years (EU 27 countries - 38.4\%), participation in higher educational levels was more significant and the employer was the main institution to prepare it or to empower it (IEFA, 2011). In the reasons mentioned for their participation, $33.2 \%^{2}$ mentioned that they were obliged to participate.

In this study, we found individuals who, despite having participated, challenged the model used considering that the contents were below what they had to learn. Alfredo (41 years/ISCED 1/unemployed/industrial ex-employee in the automobile industry), participated in company formation and questioned the objectives of this learning: "I had training, but I was a bit of a fool, because it was to see puppets about security and noises [...] and this kind of very basic things";

Susana (54 years/ISCED 2/ retired/Electric Company ex- employee), performed different functions at the company, where she attended different types of non-formal education, reported on its disconnection and (in) utility: «... I did formations that had nothing to do with the work I was doing. Were those formations that we were forced to go and that was not formation."

However, other testimonies have recognized this form of education as being useful and necessary to improve their skills and to acquire new skills to operate professionally. Bruno (41 years/ISCED 2/swimming pool maintenance), was at the company where he worked, that he experienced his first contact with non-formal education, recognizing a major role for his professional experience: " [...] every year I take a course to grow in the area ... learning between training and experience".

The main difference between the two positions above illustrated was the decision to participate. Whenever participation took the form of external imposition, the relationship brought resistance and the devaluation of its usefulness and pertinence, whereas, when it was assumed by itself, to manage its career, it gained importance and recognition as learning.

In the interviewees who were unemployed and with lower levels of schooling, and that came across the IEFP ${ }^{3}$, had the perception of the recent processes of change that characterize the relationship between formal and non-formal education, sensing the effects of their exclusion. Non-formal education began to consider as a requirement of access the level of schooling of individuals, which has left behind the least educated, reinforcing one of the forms of social inequality associated with LLL.

\footnotetext{
${ }^{1}$ Institute for Employment and Vocational Training.

2 IEFA brochure (2011: p.7).

${ }^{3}$ With its guidance services for non-formal education modalities, according to the local offer and the Catalog National Qualifications (CNQ); Information that can be consulted at CNQ of ANQEP, I.P.
} 
Pedro (62 years/ISCED 1), after farming, where he only learned the informal way, entered the field of automobile education experienced non-formal education: "I'm going to take an instructor's license [...] was the last course already done with the 4th grade/ISCED 1 [...] from there, in the following course, it was already with the 6th grade [...] today they already require the ISCED 3";

Luis (50 years/ SCED 1/unemployed), questioned about his participation in non-formal education modalities, which emerged through the Employment Center, let escape that access is differentiated, depending on the levels of education, fewer school resources, see restricted opportunities to learn: "No, it was only for those who had up to the 4th class, those who had more studies went to another".

The evidence collected in this study allowed us to support the idea defended by Jarvis and patent in the IEFA (2011), that the less educated, those in the most disadvantaged positions of the social hierarchy and also the older ones, are the ones that are farthest away of learning processes in adulthood (Jarvis, 1992: 242). At the same time, it was found that the presence of greater dependence or autonomy on the trajectories of the interviewees was directly associated with their educational levels and their ages, which in the case of the older and less educated adults accentuated these processes of exclusion and increased inequalities.

\section{"Staying out" and the relationship with the knowledge society}

The passage from the so-called "industrial society" to what some authors ${ }^{1}$ considered to be a new era (a consequence of the service economy that preceded it), gave rise to a myriad of theses and proposals of different nomenclatures to form concepts that today seem vulgar: information society and / or knowledge society. These concepts translate new relationships between societies, individuals, information, knowledge, education and learning itself, about which some care in the analyzes directed at them is important and urgent.

António Costa (2012), recalls that in the last decades the enlargement and prolongation of the education of the population, as well as the rapid increase in formal qualifications, and their assimilation into economic and social activity, together with the other transformations already mentioned, have been driving social change. Understanding schooling as a relevant indicator in the multidimensional analysis of development has been attributed to the task of empowering individuals with the "skills" needed to keep up with the rapid pace of change, preparing individuals for full integration, fostering the idea of sustainable development of an economy that is increasingly taking place around knowledge and information.

Throughout the twentieth century, despite efforts to make the public system, through its policies, serve as a vehicle for ensuring greater social equality, focusing its attention on the school system and higher education, adult education was being left at the margin of a political consensus. This lack of consensus could help to understand such disparate and unequal national participation. In Field (2006), we see the organizations dedicated to adult education based on principles guiding the great social movements: autonomy; emancipation; democracy and human rights. However, the author also underlines the presence of skepticism based on the ability of schools to play their part, as they continue to see failures in large population groups. It has alerted us to the existence of high social expectations of how we seem to assume that those with whom we meet in everyday life are apt to deal with writing, reading, and numeracy, maintaining coherent conversations, forgetting that they are real competences for people who have received a higher quality schooling, a situation that, according to the same author, reinforces the gap between the older and more new ones (idem).

By analyzing the access and use of information, within the framework of the requirements introduced by these knowledge/information societies, this study allowed to observe that individuals with low levels of schooling revealed deficits in the necessary skills to identify, autonomously, i.e. opportunities. The testimony of Sonia (34 years/ISCED 1) is an example, the research on the internet proved unable to find compatible learning solutions. In other testimonies, there was a lack of knowledge about the current EA offers in Portugal (in addition to the 'Novas Oportunidades' initiative, which expired in 2012).

On the day-to-day difficulties of those who have been excluded from formal education, the supra-referenced theoretical lines were corroborated, confirming that for individuals with schooling that was around ISCED 2 they were less-expressive, then for those with only ISCED 1. Thus, among the less educated interviewees, there were a number of difficulties that were embarrassing their lives, which resulted, in summary, in the lack of job opportunities and the lack of autonomy to use

${ }^{1}$ Robert Lane (1966); Daniel Bell (1973); Peter Drucker (1993); Nico Stehr (1994). 
services in institutions considered essential in a society which has been responsible for the individual (e.g. Finance, Health ...).

Ana (64 years/ISCED 1), worked in the cleanings and her life was spent between the field and the cleanings. When she talks about her hard work life, she reflects on having lost other opportunities: "now it's no longer worth it, I would like to find something else, but also schooling don't [...]I only have the ISCED 1 (4th) [...] if I had more, maybe I could have chosen another job.". Other difficulties were experienced in tasks that depended on the computer (e.g. the issuance of financial payment guides, requests for exemption from social security) by resorting to their proximity networks - colleagues - to circumvent them; at home, they all had ISCED 1 and could not support it.

For Sofia (34 years/ISCED 1), the level of schooling also restricted access to job opportunities, summarizing them as precarious or seasonal offers: "Many doors have closed because I only have ISCED 1 [...] I look for work, I go to restaurants ... I go everywhere, I look for [...] no arrangement, or what they pay it does not compensate [...] and this discourages me".

Madalena (62 years/ ISCED 1 incomplete), although she said that her schooling was sufficient for the life she had until her retirement, she recognized the fragility of those who didn't complete the ISCED 1, especially in writing and speaking. "so, I read I have no problems at all to read, now I say many nonsenses, because I can't speak, I can't write, because I make many mistakes."

In the interviewees whose schooling approached the ISCED 2, the difficulties were felt in another way and in another type of skills, for example, the scarce knowledge of a foreign language (English) that compromised an autonomous use of the internet, a resource that they used with regularity in their professional contexts and leisure activities.

Mário (39 years/ ISCED 2 incomplete) "... the question of English would have helped a lot ... because what you do today on the internet, to research something, has to be English."

The results of this research underscored Field's contributions (2006:113), evidencing the existence of a gap between those who 'have' and those who 'haven't" educational resources, aggravating it when it is perceived that it is more likely for those who are already 'rich in knowledge' to expand their learning/skills, leaving behind the most 'disadvantaged' prisoners of dependency networks to move and adapt, leaving aside a large number of opportunities, which extend beyond the world of work.

It should be stressed that these difficulties must reflect the limits of informal learning, which is insufficient to give the undereducated adults the skills necessary to reduce social inequalities and to integrate into a reality increasingly structured by knowledge and information.

\section{Obstacles to formal learning: situational, institutional and dispositional}

Regarding non-participation in education and training activities, IEFA (2011, p. 33- 79) revealed that $51.2 \%$ of the population between the ages of 18 and 69 didn't participate in education and training activities (formal and non-formal), and $21.9 \%$ didn't participate in any kind of education, training, and (informal) learning. The results of the IEFA (2011) left open the will to know the reasons for the two segments that participated: those who did not participate but would like to have participated $(7.8 \%)$ and those who did not participate and did not wish to participate in education or training (43,5\%). The existence of $33.9 \%$ who participated and did not want to participate more also left unanswered questions. Of the reasons there, the lack of time was indicated as one of the main obstacles to learning $(45.8 \%)$, preceded by the lack of training offer (15.3\%). The financial reasons, associated with the cost $(14.7 \%)$ and, finally, family responsibilities (11.5\%).

In this dimension, it was tried to identify the obstacles that were determining the withdraw of these adults from formal education, after the exit of the school. The alert for the need to look at this participation in education/training as something that doesn't depend only on the motivation/intention of the adults, because it also depends on their life paths and their position occupied in the social system, was in Jarvis (1992:242). In its typology on the obstacles to participation in nonformal learning - situational factors; institutional and dispositional - he explained the possibility of articulation between them. Situational factors were related to professional and family life, while institutional factors referred to the existing offer and its disclosure. The attitudes of individuals to the frequency of training actions were the dispositional factors (Jarvis, 1992: 245). In the case of low-schooling adults, this combination of factors was also found, so that non-participation in formal education could be dependent on the lack of objective conditions, especially on the part of employers(which encourage and enable the registration of these practices); of institutional offers are considered insufficient or inadequate (time, location, model); 
or personal dispositions in relation to education/training are negative, leaving receive previous unsuccessful school experiences, such as those that have already been described here (Ávila, 2008).

In all the speeches of these interviewees were found, cumulatively, situational, institutional and dispositional factors. In the situational factors, the role of the professional context and the family as determinant forces for the (non) participation in formal education, either by the type of functions (different levels of complexity, devaluation of formal certification), or by the existence of tensions in the compatibility of different dimensions of the life of the individuals (work, family and other activities).

\section{Situational and dispositional factors}

Ana (64 years/ISCED 1), began to work in sewing, then in industry and agriculture. She was currently working in the cleanings. The main obstacle to returning to formal education was the fact that she had not had time to think about it and that the activities she had developed had not made her feel that it was worth investing in schooling "I never thought it, because either I was in country, or I was housekeeping";

Alfredo (41 years) started working in a car workshop, then went to a factory, left and went to an electrometallurgy where he worked as an assistant to a $\mathrm{CNC}^{1}$ operator. (19) Later he worked as an assembler of pieces 3rd in a factory of automotive components. He never felt the need to improve his schooling because he considered it sufficient for the jobs he was arranging. "I didn't need more ... it was all manual labor, because I like to do manual labor, so I didn't feel this difficulty ";

Sergio (34 years/ISCED 2 incomplete), always worked with his father, so schooling was not important, he just needed to show what he knew "doing". Their priority was to be professionally integrated. The justification for not resuming formal education processes was the absence of a request/requirement of any certificate: "they say that I don't need it, because it is enough for people to see me do things".

Bela (50 years/ISCED 1), her first job was to "serve"2 and the professional career was little diversified, inhibiting the need to increase her schooling. It revealed certain conformity, reflected in the idea of naturalization of the place/position occupied, arguing that in society there must also be people who perform those functions. "Not. I thought it might be a little late, but I figured there had to be people doing the work I do, too";

Ramiro (62 years/ISCED 1), knew the offers for adults but never had time to think about them, because of work. Being unemployed he considered that the offers were for who had the time and could. He would not be able to survive on unemployment benefit alone, and he would have to devote time to agriculture and animal husbandry: "my job didn't give me the opportunity to study because I got up at 6:30 in the morning, and only came home around 11:00 pm [...] is for those who have available times [...] for Who has nothing else to do.".

The tensions between reconciling a "return to school" and family life were also present in the above-mentioned obstacles:

Mário (39 years old / ISCED 2 incomplete): "The fact that I am having this conversation here ... makes my wife have to be at her mother's house with her two daughters and give them dinner there [...] when I leave work ... I can't go to school."

The dispositional factors, found in most respondents, did not always reflect the negative view of education and training as a consequence of previous experiences, but converged with the idea of willingness as a "manifestation of will," to act and to believe (Lahire, 2005), adding to the motives presented, judgments about their usefulness, necessity and place, as a non-integral part of their personal projects in the short, medium and long term. They have been scattered in arguments related to their experience of the school, and with the fact that they were not motivated, throughout their life trajectories, to resume formal education:

Ana (64 years/ISCED 1) confesses that she got tired of school "I never thought about it, and I never had anyone to support me, we were so tired of school!"

Economic difficulties made the priority of individuals fall back on activities from which income could be withdrawn, allowing the subsistence of the household, inhibiting the desire, or the possibility of participating in or resuming formal education.

\footnotetext{
${ }^{1}$ Computer-assisted numerical control.

2 Domestic work in the form of boarding school in other people's homes.
} 
The presence of these difficulties is found in Ana's discourse on her husband, who never thought of resuming formal education: "Not because his life too ... made the fourth class and then also wanted to make money ... went to the tulips, lay the woods down, it was his life to throw the woods down, however, he went to the troop, came from the troop and went to agriculture. He was 8 years old employed in the chamber, in the gardens, and now he is retired, and if anything appears to him, even from the outside, to tell him to do this or that, he will."

Luis (50 years/ISCED 1), there were six siblings at home and the work happened at school time: "It was a full house, that's why we worked for each other. It's not easy, it was "you can't go to school, you have to go to work"; we all were like this. I think only one brother of mine went to study ... the youngest."

In the speeches it was possible to find a certain "comfort" in the life that happened with that schooling, accompanied by skepticism about the return of an investment in formal education. The interviewees acknowledged that the frequency of education/training actions was not compatible with the need to work, reflecting the idea that was something addressed to those who had [time/financial] availability, showing a short-term overlap of needs [here and now] with the idea of a project that, in the long term, could improve their living conditions.

Luis (50 years/ISCED 1): "then I walk here information, now I have no unemployment fund [...] I cannot walk here ... what's the use of a guy coming to spend a hand full of money, if a guy comes to an end and has no job because they have a younger one?"

Pedro (62 years/ISCED 1): "for those who have spare time [...] for those who have nothing else to do ... unemployment cannot survive, I have to have some vegetables and some jobs".

Two of the interviewees also mentioned depression as an obstacle to learning because it inhibited their ability to learn. One of the ladies summoned the idea of a 'domestic trap' (Lahire, 2005: 5), as a consequence of marriage to a less educated person and the fear of conflicts, in this case the obstacle arose beyond his "will to act".

Bela (50 years/ISCED 1): "no, I never think about it! my husband is an old-fashioned person. Sometimes, I thought about going back to school [...] I thought about moving forward in life [...] but it will be very bad for both [...] it didn't have the courage";

In older adults, age was also often cited as a reason to stay out of formal education offer:

Pedro (62 years/ISCED 1), considered that it wasn't an offer for his age since it wouldn't change his condition to work: "if there is such great unemployment for young people ... I don't say that it is not good to create knowledge [...]but we shouldn't create the false perspective of thinking that we have a future ahead because our future is over!"

\section{Institutional factors}

Although less expressive, the institutional factors reflected the instability of the AE offers in Portugal, making pathways confusing and inhibiting those who considered resuming formal education. Some of the interviewees also referred to the New Opportunities as the current offer, revealing total ignorance of its closure and the offers that preceded it. This lack of knowledge should serve as an alert for an urgent reflection aggravated by the fact that we are facing another setback in AE's history. This return of adults to formal education seems to be dependent on educational policies without concrete guidelines and without a goal action scheme since the volatility of current offerings makes them poorly disclosed and therefore unknown. Thus, these offers seem to be unable to reach the target audience for whom they are supposed to be: adults (especially the less educated).

Ana (64 years/ISCED 1), didn't know the offer available: "I haven't heard of any, I don't know if it is the same ";

Sérgio (34 years/ISCED 2 incomplete): "I know there's something I sometimes hear, but I don't do much of it ... because I'm not interested";

Along with this lack of knowledge, the schedules, duration, cost, location and difficulty associated with transportation were also mentioned, making it impossible to achieve a return, in cases where the idea arose.

Bruno (41 years/ISCED 2 incomplete), was unaware of the closure of the New Opportunities Initiative (INO): "Are the new opportunities already over? I didn't know."; had the opportunity to attend a double certification course, completing the 
ISCED 2, but the distance and the investment stopped him: "it was equivalent to the 9th grade, but I had to go there for 3 years! It was too expensive to go to Peniche every day."

Sofia (34 years/ ISCED 1), tried to resume, without success, formal and non-formal education. The reasons for failure were associated with the cost of training and the lack of transportation (and the combination of the two): "Yes, I went to ADRO at the time to take the ISCED 2 at night, but because I lived in Outeiro [...] I don't have a license, and didn't have a car [...] something appeared on Facebook ... I called and it was 200 euros a month, I called, but it was in Lisbon; I couldn't make it!".

\section{The under-educated adults' dispositions on education}

In the life trajectories of these interviewees were found different views on education, which reflected the relationship that these were maintaining with it and the place it was occupying. Field (2006) argued that, about education, two visions could be found: a positive one, for those who worked in education and for whom education was emancipatory and meaningful; and a negative, reflexed in a form of coercion, repeated failure, not being a personal choice or identity, but part of instructions given by others. Thus, if for some individuals it would arise as something that had to be done to survive in a society of risk, for others, these "opportunities" of education made available simply didn't matter. It is equally interesting to see how society sees each of these groups. On the one hand, there are about those who don't participate, the idea that they are victims of bad social and psychological structures, since they have denied them the possibility of equal access to the so-called "positive" learning opportunities and, on the other hand, in active processes of self-exclusion a form of resistance (e.g. when adults reported that education wasn't for them, or that they had no head/capacity to study).

In Jarvis, we read that different phases of history corresponded to different views on education. Thus, if in the first phase education represented an investment that reflected on employability, in the second stage education was a vehicle for selfdevelopment (spiritual; active citizenship). In a third, more recent, critical and resilient phase LLL came to be associated with lifelong work. This premise echoes the idea of the speed of change, where individuals have been forced to risk, learn, reflect and act, trying to find its own adjustment to changes, in a continuous cycle (Jarvis, 2004).

The existence of distinct visions and phases, which transcend individuals, gave meaning to the analysis of their dispositions on education. Lahire (2005) distinguished strong and weak dispositions, depending on the intensity of socialization and the degree of fixation/force. Durable habits would take time to be incorporated and some dispositions might fade because of an upgrade or void in the face of repression/crisis. However, it would also be possible for socialized individuals to internalize a certain number of habits (cultural, intellectual) without having the will to put them into action, being the action stuck only to the weight of routine, automatism/habit or obligation. The internalized habits could be updated in the presence of constraints/obligation, passion/desire, or even unconscious will/routine, everything would depend on the form and timing of the individual biography in which these dispositions were acquired, as well as on the current context of their actualization.

In this research, we wanted to realize if the relation that these adults established with education interfered and molded the vision that they had about it. The main conclusions showed that the action of these individuals in the face of formal education wasn't always in line with their general view of education. Between initial education (child/youth) and AE, the main difference found was mainly the devaluation of the latter, which may have justified a more skeptical and less enthusiastic position, considering that, for these adults, it represented only one-second chance. As a means of schooling, the AE was seen by these individuals as a measure incapable of eliminating the previous difficulties, making them even more visible. The idea that society doesn't recognize the $\mathrm{AE}$, devaluating its participation, was highlighted in the speeches of those who said that it doesn't teach the same thing, or that adults and the youth don't have the same capacity to learn.

\section{Instrumental view on initial education}

Ana (64 years/ISCED 1), mirrored an instrumental view on education, alerting her granddaughter to the importance of studying to "be someone": "Look, take advantage of it, to see if you can ever be someone! before it was not compulsory to walk in school as it is now. We could get the driving license with the fourth class";

Luis (50 years old / ISCED 1), was sorry he did not continue in school. For him to learn was to be faced with the news, was to be someone, underlining the same instrumental vision, while advocating that true learning happens outside of school: "children should start at age 15 to have a job. I may not know how to read or write, but I know a lot that a lot of people do not know, because the things I've learned in my life have been learning over time". 
In other testimonies, it was clear the disinterest accompanied by the questioning about the real need for formal education, expressed in a relationship that forces them to follow instructions from thirds (Field, 2006). These visions of resistance fueled the dispositions towards learning, marking an intentional withdraw from the different modalities that were available in the different stages of their lives:

Sérgio (34 years/ISCED 2 incomplete), never felt the need to have more schooling, devaluing formal education and certificates. He valued daily the "know-how": "I already have 34 years, I need to have a job, and not to have courses! if I have work, I'm ok ... I have always worked on my own, so I didn't need to have the 9th grade." This final idea also corroborates the IEFA data on the lower probability of participation of TCP ${ }^{1}$ in education and training activities.

Bruno's vision (41 years/ISCED 2) on AE left two conflicting ideas oscillating between a path of access to more culture and a mandatory measure that, for the majority, only served to pass the time. It acknowledged its usefulness in job-seeking but devalued its impact on changing or improving work conditions. For Bruno, the focus of EA was the older adults and the reason for its existence was unemployment: "for people to be a little more educated, but for others, I think it is way of passing time, nothing else because they are almost obliged to be there ... I think if there was work, enough work people studied less. They wouldn't take these courses, because they weren't obliged. ";

The same instrumental vision is found in Madalena (62 years/ISCED 1 incomplete), when she recognized that it was possible to go further studying. About AE stated that it wasn't for herself, mirroring a self-image that seemed to confirm the said self-exclusion referred by Jarvis (2004). For the elders, she considered that the AE would be a mere occupation. She believed in strong disparities between the education of young people and the adult's education, from the type of education to their capacities to learn: "Those old people who stopped, they go to computers, to universities. I think society doesn't look them the same way they look at young people in initial education! I think that when you go from the 1st to the 12th year you have another capacity, which you don't have if you learn in the middle... no, I don' have the head for it, I'm a bit outdated ... but it's not for me."

The remaining views oscillated between the functionalist vision with a direct impact on employability, although they were limited to triggering convergent action schemes along their trajectories, in which the feeling that they had lost the train persisted and that there was nothing else to do, except to conform to the idea; and a less positive view of education, considering it unnecessary, justifying its absence along the trajectories (Jarvis, 2004). The removal, in these situations, happened because the different professional paths did not make it necessary.

\section{Views on education related to self-development, found in the most schooled}

None of the interviewees participated in citizenship activities at the time of the interview, and their daily life was organized between work and family so that the vision of self-development was not found with reflexes in the exercise of active citizenship (Jarvis, 2004). Leisure activities integrated, in an uneven way, the daily life of these adults, making only part of the trajectories of those who came closer to ISCED 2.

The analysis of the different views on education made it possible to conclude that in this group of interviewees the informal type of learning was the most frequent and accessible, expressed in the use of proximity networks. However, this way of learning was more autonomous and/or complex when the level of schooling of individuals was higher (e.g. the use of other learning as the internet) because they depend on other skills. The non-formal learning, in most cases imposed, was accompanied by tensions and resistance, and the recognition given to its utility in everyday life was scarce.

In the analysis of the dispositions with respect to formal education, the relationship that each of them established with the initial education and the moment of rupture/abandonment or withdrawal was found in all individuals. These results express the impacts of socialization in families of mostly rural origin, in which the internalization of habits reflected the appropriation of short-term strategies (here and now) and of "unleashing" before the challenges that the speed of social changes has put them. These dispositions were, unequally, leaving out of their individual paths the return to formal education processes. Consequently, if for the elders, to whom it imposed itself compulsorily (unemployment), the need to subsist economically kept them on the sidelines. For the youngest, for whom it seemed unnecessary, it translated only one hypothesis to consider in case of unemployment, illustrating the moment of updating provisions, by constraints/crisis, predicted in Lahire (2005).

${ }^{1}$ TCP - Self-Employed Worker. 


\section{Conclusions}

The relationship of the low-educated adults who didn't return to formal education with LLL showed the presence of their dispositions in relation to the initial education, considering them the origin of the reasons that led them to leave school.

These withdraw didn't inhibit informal learning, but brought it differently, according to the level of schooling obtained, reflecting a greater or lesser autonomy in relation to the challenges imposed by society. Nevertheless, the informality of those learnings in the daily life of these adults are neither acknowledged by them nor by society as effective and/or relevant learnings, as they don't translate into certificates or diplomas, continuing to be "left outside" from the social system the same individuals that until now remained far from formal education.

The perceptions about non-formal education (disconnected and useless) also corroborated a relation of distance with the modalities considered "qualifiers" of LLL. This relationship contains an idea of "accommodation" in relation to the places occupied in social life and of "unleashing" the challenges of everyday life. In the dispositions of these individuals in relation to LLL, the existence of a conscious perception of the processes of exclusion associated to them was revealed, although this wasn't enough to provoke an updating constraint of dispositions and internalized habits, thus precipitating the action.

One of the conclusions considered as alert and leitmotiv for a reflection among those responsible for educational policies is the presence of a devaluation of formal education and stigmatization of $A E$. In the analysis of the dispositions of these adults, there was a strong association of formal education with initial education, and the adult education reflected a less efficient learning, unrecognized socially and professionally. It was perceived as a resource for the unemployed and for the elders.

These conclusions should aware us of the need to better understand the internalization of habits and values about LLL, allowing effective intervention in the face of a chronic problem that results in the association of low levels of schooling with a lack of participation in educational and training activities of the low educated Portuguese population.

\section{Bibliographic References}

[1] Alves, Nuno de Almeida, Frederico Cantante, Inês Baptista, e Renato Miguel do Carmo (2011), Jovens em Transições Precárias. Trabalho, Quotidiano e Futuro, Lisboa, Editora Mundos Sociais.

[2] Ávila, Patrícia (2007), "Literacia e desigualdades sociais na sociedade do conhecimento", em António Firmino da Costa, Fernando Luís Machado e Patrícia Ávila (org), Portugal no Contexto Europeu, vol. II, Sociedade e Conhecimento, Lisboa, Celta Editora, pp. 21-41.

[3] Ávila, Patrícia (2008), A Literacia dos Adultos. Competências-Chave na Sociedade do Conhecimento, Lisboa, Celta Editora.

[4] Bell, Daniel $(1973,1976,1999)$, The Coming if Post-Industrial Society. A Venture in Social Forecasting, Nova lorque, Basic Books.

[5] Benavente, Ana, Alexandre Rosa, António Firmino da Costa, e Patrícia Ávila (1996), A Literacia em Portugal. Resultados de uma Pesquisa Extensiva e Monográfica, Lisboa, Fundação Calouste Gulbenkian / Conselho Nacional de Educação.

[6] Costa, António Firmino (2012), "Sociedade do conhecimento e desigualdades em Portugal e na Europa", em António Firmino da Costa, Desigualdades Sociais Contemporâneas, Lisboa, Editora Mundos Sociais, pp. 111127.

[7] Drücker, Peter F. (1993), Pós-Capitalist Society, Nova lorque, HarperCollins Publishers.

[8] Drücker, Peter F. (1969), The Age of Discontinuity, Guidelines to Our Changing Society,1st edition, Londres, William Heinemann, Ltd.

[9] Enguita, Mariano Fernández (2007), Educação e Transformação Social, Mangualde, Edições Pedago, Lda.

[10] Benavente, Ana, Jean Campiche, Teresa Seabra, e João Sebastião (1994), Renunciar à Escola. O Abandono Escolar no Ensino Básico, Lisboa, Fim de Século.

[11] Ferrão, João, Fernando Honório, Ana Nunes de Almeida, Isabel Margarida André, Filipa Ferrão, e Dora Possidónio (2000), Saída Prematura do Sistema Educativo. Aspectos da Situação, Causas e Perspectivas em termos de Emprego e Formação, Lisboa, OEFP.

[12] Field, John (2006), Lifelong Learning and the New Educational Order, Londres, Trentham Books. 
[13] Guerreiro, M. Dores, e Pedro Abrantes (2004), Transições Incertas. Os Jovens Perante o Trabalho e a Família, Lisboa, DGEEP/MAET, cap. VI.

[14] Jarvis, Peter (1992), Perspectives on Adult Education and Training in Europe, Leicester, National Institute of Adult Continuing Education.

[15] Jarvis, Peter (1983, 1995, 2004), Adult Education and Lifelong Learning, Londres, Taylor\&Francis e-Library.

[16] Lahire, Bernard (2005), "Patrimónios Individuais de Disposições. Para uma Sociologia à Escala Individual", Sociologia, Problemas e Práticas, 49, pp. 11-42.

[17] Lane, Robert E. (1966), "The decline of politics and ideology in a knowledgeable society", American Sociological Review, 31, pp. 649-662.

[18] Massey, Douglas S. (2007), Categorical Unequal. The American Stratification System, Nova lorque, Russel Sage Foundation.

[19] Rodrigues, Maria de Lurdes, João Sebastião, João Trocado da Mata, Luís Capucha, Luísa Araújo, Mariana Vieira da Silva, e Valter Lemos (2014), "A construção do sistema democrático de ensino", em Maria de Lurdes Rodrigues (org.), 40 Anos de Políticas de Educação em Portugal, volume I, A Construção do Sistema Democrático de Ensino, Lisboa, Almedina, pp. 35-88.

[20] Seabra, Teresa (2010), Adaptação e Adversidade. O Desempenho Escolar dos Alunos de Origem Indiana e Cabo-Verdiana no Ensino Básico, Lisboa, ICS, Imprensa de Ciências Sociais.

[21] Seabra, Teresa (coord.), Sandra Mateus, Elisabete Rodrigues e Magda Nico (2011), Trajetos e projetos de jovens descendentes de imigrantes à saída da escolaridade básica, Lisboa, Observatório da Imigração, ACIDI, I.P., pp. 82-90.

[22] Stehr, Nico (1994), Knowledge Societies, Londres, Sage.

[23] Therborn, Göran (2006), "Meaning, mechanisms, patterns, and forces: an introduction", em Göran Therborn (ed.), Inequalities of the World. New Theoretical Frameworks, Multiple Empirical Approaches, Londres, Verso, pp. $1-58$. 
